\title{
Leisure-time physical activity as a protective factor for functional capacity loss in community dwelling elders
}

\author{
Maria Claudia Martins Ribeiro ${ }^{(\mathbb{0})}$, Adriana Sañudo ${ }^{a}$, Luiz Roberto Ramos ${ }^{a, *}$ (1)
}

\section{Keywords:}

Independent living;

Exercise;

Cross-sectional study; Aging;

\begin{abstract}
Populational aging led to the emergence of chronic diseases, all potentially incapacitating, thus affecting functional capacity (FC) of elders. Despite health evidences in favour of having regular physical activity, the majority of elders are not sufficiently active. Baseline data of an urban elder cohort in Brazil showed that only $28 \%$ were active and $68 \%$ had some functional loss, a figure that went up to $73 \%$ among the inactives. FC was associated with a network of sociodemographic, health and behavioral factors. In a multivariate analysis, the inactives showed twice the odds of being severely dependent when compared to the actives. Noteworthy that inactivity is as a modifiable factor that might prevent FC loss. Longitudinal studies are needed to verify.
\end{abstract}

\section{RESUMO}

O envelhecimento populacional gera o surgimento de doenças crônicas, todas potencialmente incapacitantes, afetando a capacidade funcional (CF) dos idosos. Apesar das evidências de saúde em favor da atividade física regular, a maioria dos idosos não é suficientemente ativa. Dados da linha de base de uma coorte de idosos no Brasil mostraram que $28 \%$ eram ativos e $68 \%$ tiveram alguma perda funcional, número que subiu para $73 \%$ entre os inativos. A CF se associou a uma rede de fatores sociodemográficos, de saúde e comportamentais. Na análise multivariada, os inativos mostraram duas vezes mais chances de serem dependentes graves quando comparados aos ativos. Destaca-se a inatividade como um fator modificável que pode prevenir a perda da CF. Estudos longitudinais são necessários para verificar a causalidade.

\section{RESUMEN}

El envejecimiento poblacional causa aparición de enfermedades crónicas, potencialmente incapacitantes, afectando la capacidad funcional (CF) del anciano. A pesar de evidencias se salud a favor de la actividad física regular, la mayoría de los ancianos no son suficientemente activos. Una cohorte de ancianos brasileños mostró que $28 \%$ estaban activos y $68 \%$ tenían alguna pérdida funcional, cifra que subió al $73 \%$ entre los inactivos. La CF se ha asociado con una red de factores sociodemográficos, de salud y comportamiento. En análisis multivariante, los inactivos tenían el doble de probabilidades de ser dependientes severos comparándolos con los activos. La inactividad se destaca como un factor modificable que puede prevenir la pérdida de CF. Se necesitan estudios longitudinales para verificar la causalidad.

\footnotetext{
a Universidade Federal de São Paulo, Escola Paulista de Medicina, Departamento de Medicina Preventiva, São Paulo, SP, Brasil.
}

\footnotetext{
* Autor correspondente: Luiz Roberto Ramos

E-mail: Irramos1953@gmail.com
}

Recebido em 13 de fevereiro de 2020; Aceito em 17 de março de 2020. 


\section{INTRODUCTION}

Population aging is a worldwide phenomenon and the Brazilian population is aging faster than the world average (UNDESA, 2017), (Simões, 2016). The demographic transition has led to the emergence of chronic non-communicable diseases (CNCD), all potentially incapacitating, thus affecting functional capacity (FC) of elders that usually present polimorbidity (Ramos 2003; Ramos et al, 2016; Nunes et al, 2018). Loss of independence in daily life has been shown to significantly increase mortality risk among elders, after controlling for all related variables (Ramos et al, 2001). Good FC represents a new concept of good health status and is indicative of healthy aging (Ramos 2003). In fact, is the degree of independence and autonomy in daily life that will indicate who is at risk for hospitalization, institutionalization and death (Ramos et al, 1993; Ramos et al, 2001; Ramos et al, 2013; Santos et al, 2008; Lima-Costa et al, 2011). Although being influenced by CNCD, FC is mainly associated with lifestyle factors like smoking, drinking, eating habits, having social relations and exercising (Santos et al, 2008; Zang\&Feldman 2019).

The World Health Organization (WHO) points to physical inactivity as the fourth major risk factor for mortality and to regular physical activity (PA) as one of the main determinants of active and healthy aging with evidences that it improves quality of life, reduces disability and maintain FC (WHO, 2005; WHO, 2015; US, 2018). The linear relationship between the PA and the health of the aged is consolidated and has been presented by numerous studies that demonstrate its physical, psychological, social and functional benefits for the elders (Paterson\&Warburton, 2010; Tak et al, 2013; Bauman et al,2016). Several authors have found positive associations of an active lifestyle and good FC during the aging process (Bauman et al 2016; Rennemark et al, 2018). Despite the evidences in favor of PA, older people are still mostly inactive (Rennemark et al, 2018; Guthold et al, 2018). In Brazil, only $22 \%$ of those aged 65y or more referred adequate levels of leisure-time physical activity (MS, 2017).

Several intervention studies promoting leisuretime physical activity (LTPA) have found that regular physical activity is a health protective factor (Valério et al, 2014; Novais et al, 2019). However, few studies have evaluated the impact of LTPA on the degree of independence in the activities of daily living (ADL) (Ferreira et al, 2010; Dos Santos et al, 2018). Thus, understanding the factors related to a good FC of the elderly can help the planning of public policies aiming at the manteinance of functional independence of the elderly in the community for as long as possible.
The objective of this study is to analyze the association of LTPA with the FC of olders residents in a large urban center in Brazil, controlling for sociodemographic, behavioral and health-related variables.

\section{METHODS}

We analyzed secondary data from a cohort of people aged 60 years or more, highly educated, living in a middle-class neighborhood in the city of São Paulo. The cohort was established after a census that served as the basis for a household survey in 2008 (Ramos et al., 2013). After the home interview all respondents $(n=1,799)$ were invited to participate in the cohort baseline. A total 1,155 elders attended the invitation and had a complete geriatric and gerontological evaluation. Of this total, only 907 elders answered the questionnaire to assess PA level and constituted the study population.

The outcome variable was FC, measured by a validated questionnaire (Brazilian version of OARS Multidimensional Functional Assessment Questionnaire - BOMFAQ) with questions about the limitations to perform 15 ADL (Ramos \& Goihman, 1989). A continuous variable from 0-15 limitations was categorized as: zero limitation (independent), 1-3 limitations (mild dependence), 4-6 (moderate) and $\geq 7$ (severe).

The main variable of interest was minutes per week of LTPA measured by the International Physical Activity Questionnaire (IPAQ), validated in 12 countries, including Brazil (Craig et al, 2003). This study classified the elders in: inactive ( $<10$ minutes of moderate LTPA) week), insufficiently active ( $\geq 10$ and $<150 \mathrm{~min})$ and active ( $\geq 150 \mathrm{~min})$.

Other independent variables considered were: gender; age; marital status; years of school; income; body mass index; number of diagnoses; number of drugs used; dysthymia; alcohol and tobacco consumption.

We used Chi-square test and Cramer $\mathrm{V}$ analysis to evaluate the statistical significance and the strength of the association of each variable with FC.

For the multivariate adjustment, we selected all the variables that in the univariate analysis showed $p<0.20$. The variables that were not statistical significant ( $p>0.05)$ in initial multivariate model, were excluded to obtain the final model. The results were presented as odds ratios (OR) and confidence intervals of $95 \%$ $(95 \% \mathrm{Cl})$. In all multivariate analyzes, the gender variable remained in the model as an adjustment variable.

All statistical analysis was performed in STATA / SE v.15.1 with and a significance level of $5 \%$ was adopted.

The study was approved by the Ethics Committee of the Universidade Federal de São Paulo/Hospital São Paulo (no 2.381.375, on 11/14/2017). 


\section{RESULTS}

Among the respondents the majority consisted of women (67\%) and people over 70y (65\%). More than $65 \%$ of them had 8 or more years of schooling and $52 \%$ had income between 4 and 10 minimum wages. Among the variables related to health, the majority took 5 or more medications (51\%); and $30 \%$ present dysthymia. Regarding the LTPA, 28\% were active, $17 \%$ insufficiently active and $55 \%$ inactive. The $\mathrm{FC}$ assessment showed that $32 \%$ were independent, $42 \%$ mild, $13 \%$ moderately, and $14 \%$ severely dependent.

Tables $1 \mathrm{a}$ and $1 \mathrm{~b}$ show that all sociodemographics and health related variables were associated with FC. Table 1c shows LTPA as a protective factor of FC. Among the inactives, $61 \%$ and $68 \%$ presented moderate or severe dependence, respectively. Among the actives, $19 \%$ were severely dependent. According to Cramer's $V$ analysis, dysthymia was the variable with the highest association strength.
The variables that were selected in the univariate analysis for the multivariate adjustment were gender, age, BMI, number of diagnostics, number of durgs, dysthymia and LTPA. Table 2 shows that those older than $80 y$, with more than 7 diagnoses, overweighted or obese had higher chance of having 1-3 limitations. Those aged 70 years or more, obese, inactive and presenting dysthymia showed a higher chance of having 4-6 limitations. The most dependent (7+ limitations) were those aged $70 y$ or more, overweighted and obese, inactives and presenting dysthymia.

\section{DISCUSSION}

Our study points to the protective effect of LTPA on FC indicating that inactive elders, when compared to the active ones, have twice the chance to present severe dependence. To analyze this association, we used validated instruments to measure both LTPA and FC (Craig et al, 2003; Ramos \& Goihman 1989).

Table 1a. Distribution of sociodemographic data, according to ADL in population sample of elders living in the community in Sao Paulo.

\begin{tabular}{|c|c|c|c|c|c|c|c|c|c|c|c|c|}
\hline \multirow{3}{*}{ Variables } & \multicolumn{10}{|c|}{ ADL Score } & \multirow{3}{*}{ p } & \multirow{3}{*}{ Crammer's V } \\
\hline & \multicolumn{2}{|c|}{$\begin{array}{l}\text { Total } \\
\mathrm{N}=907\end{array}$} & \multicolumn{2}{|c|}{$\begin{array}{c}\text { Independent } \\
\mathrm{N}=\mathbf{2 8 8} \\
(\mathbf{3 1 . 7 \% )}\end{array}$} & \multicolumn{2}{|c|}{$\begin{array}{c}\text { Mild } \\
\text { dependence } \\
\mathrm{N}=376(41.5 \%)\end{array}$} & \multicolumn{2}{|c|}{$\begin{array}{c}\text { Moderate } \\
\quad \mathrm{N}=114 \\
(12.6 \%)\end{array}$} & \multicolumn{2}{|c|}{$\begin{array}{l}\text { Severe } \\
N=129 \\
(14.2 \%)\end{array}$} & & \\
\hline & $\mathbf{N}$ & $\%$ & $\mathbf{N}$ & $\%$ & $\mathbf{N}$ & $\%$ & $\mathbf{N}$ & $\%$ & $\mathbf{N}$ & $\%$ & & \\
\hline Sex & & & & & & & & & & & 0.001 & 0.138 \\
\hline Male & 297 & 32.8 & 104 & 36.1 & 139 & 37.0 & 28 & 24.6 & 26 & 20.2 & & \\
\hline Female & 610 & 67.2 & 184 & 63.9 & 237 & 63.0 & 86 & 75.4 & 103 & 79.8 & & \\
\hline Age & & & & & & & & & & & $<0.001$ & 0.217 \\
\hline $60-69$ & 316 & 34.8 & 137 & 47.5 & 134 & 35.6 & 24 & 21.1 & 21 & 16.3 & & \\
\hline $70-79$ & 382 & 42.1 & 117 & 40.6 & 165 & 43.8 & 51 & 47.7 & 49 & 38.0 & & \\
\hline$\geq 80$ & 209 & 23.1 & 34 & 11.9 & 77 & 20.5 & 39 & 34.2 & 59 & 45.7 & & \\
\hline Marital status & & & & & & & & & & & $<0.001$ & 0.166 \\
\hline Married & 471 & 52.0 & 163 & 56.6 & 212 & 56.5 & 53 & 46.5 & 43 & 33.3 & & \\
\hline Not married & 435 & 48.0 & 125 & 43.4 & 163 & 43.5 & 61 & 53.5 & 86 & 66.7 & & \\
\hline Years of study & & & & & & & & & & & $<0.001$ & 0.134 \\
\hline$\geq 8$ & 601 & 66.3 & 211 & 73.3 & 259 & 68.9 & 68 & 59.7 & 63 & 48.8 & & \\
\hline $4-7$ & 240 & 26.5 & 59 & 20.5 & 99 & 26.3 & 34 & 29.8 & 48 & 37.2 & & \\
\hline$\leq 3$ & 66 & 7.2 & 18 & 6.2 & 18 & 4.8 & 12 & 10.5 & 18 & 14.0 & & \\
\hline Income (MW) & & & & & & & & & & & 0.007 & 0.091 \\
\hline$\leq 1$ & 95 & 10.5 & 28 & 9.7 & 29 & 7.7 & 15 & 13.2 & 23 & 17.8 & & \\
\hline $2-3$ & 204 & 22.5 & 57 & 19.8 & 83 & 22.1 & 31 & 27.2 & 33 & 25.6 & & \\
\hline $4-10$ & 476 & 52.5 & 162 & 56.3 & 196 & 52.1 & 55 & 48.2 & 63 & 48.8 & & \\
\hline$>10$ & 132 & 14.5 & 41 & 14.2 & 68 & 18.1 & 13 & 11.4 & 10 & 7.8 & & \\
\hline
\end{tabular}

MW: Minimum wage; ADL: Activities of daily living. 
Table 1b. Distribution of health data, according to ADL in population sample of elders living in the community in Sao Paulo.

\begin{tabular}{|c|c|c|c|c|c|c|c|c|c|c|c|c|}
\hline \multirow{3}{*}{ Variables } & & & \multicolumn{8}{|c|}{ ADL Score } & \multirow{3}{*}{$\mathbf{p}$} & \multirow{3}{*}{ Crammer'sV } \\
\hline & \multicolumn{2}{|c|}{$\begin{array}{c}\text { Total } \\
\mathrm{N}=907\end{array}$} & \multicolumn{2}{|c|}{$\begin{array}{c}\text { Independent } \\
\qquad \begin{array}{c}\mathrm{N}=\mathbf{2 8 8} \\
(31.7 \%)\end{array}\end{array}$} & \multicolumn{2}{|c|}{$\begin{array}{c}\text { Mild } \\
\text { dependence } \\
\mathrm{N}=376(\mathbf{4 1 . 5 \% )}\end{array}$} & \multicolumn{2}{|c|}{$\begin{array}{c}\text { Moderate } \\
\mathrm{N}=114(12.6 \%)\end{array}$} & \multicolumn{2}{|c|}{$\begin{array}{c}\text { Severe } \\
\mathrm{N}=129(14.2 \%)\end{array}$} & & \\
\hline & $\mathbf{N}$ & $\%$ & $\mathbf{N}$ & $\%$ & $\mathbf{N}$ & $\%$ & $\mathbf{N}$ & $\%$ & $\mathbf{N}$ & $\%$ & & \\
\hline Nr Diagnoses & & & & & & & & & & & $<0.001$ & 0.201 \\
\hline $0-2$ & 35 & 3.9 & 21 & 7.3 & 12 & 3.2 & 1 & 0.9 & 1 & 0.8 & & \\
\hline $3-6$ & 277 & 30.5 & 131 & 45.5 & 111 & 29.5 & 19 & 16.7 & 16 & 12.4 & & \\
\hline $7-9$ & 283 & 42.2 & 81 & 28.1 & 126 & 33.5 & 42 & 36.8 & 34 & 26.3 & & \\
\hline$\geq 10$ & 312 & 34.4 & 55 & 19.1 & 127 & 33.8 & 52 & 45.6 & 78 & 60.5 & & \\
\hline Nr Drugs & & & & & & & & & & & $<0.001$ & 0.170 \\
\hline Do not take & 63 & 7.0 & 27 & 9.4 & 28 & 7.4 & 5 & 4.4 & 3 & 2.3 & & \\
\hline $1-4$ & 381 & 42.0 & 145 & 50.3 & 171 & 45.5 & 33 & 28.9 & 32 & 24.8 & & \\
\hline$\geq 5$ & 463 & 51.0 & 116 & 40.3 & 177 & 47.1 & 76 & 66.7 & 94 & 72.9 & & \\
\hline Dysthymia & & & & & & & & & & & $<0.001$ & 0.283 \\
\hline Negative $(<5)$ & 709 & 78.2 & 254 & 88.2 & 308 & 81.9 & 78 & 68.4 & 69 & 53.5 & & \\
\hline Positive $(\geq 5)$ & 198 & 21.8 & 34 & 11.8 & 68 & 18.1 & 36 & 31.6 & 60 & 46.5 & & \\
\hline BMI & & & & & & & & & & & $<0.001$ & 0.131 \\
\hline Eutrophic & 398 & 45.9 & 146 & 54.3 & 160 & 44.1 & 44 & 40.4 & 48 & 39.0 & & \\
\hline Low weight & 150 & 17.3 & 61 & 22.7 & 60 & 16.5 & 14 & 12.8 & 15 & 12.0 & & \\
\hline Overweight & 115 & 13.3 & 23 & 8.5 & 60 & 16.5 & 13 & 11.9 & 19 & 15.1 & & \\
\hline Obese & 204 & 23.5 & 39 & 14.5 & 83 & 22.9 & 38 & 34.9 & 44 & 35.9 & & \\
\hline
\end{tabular}

BMI: Body mass index $\left(\mathrm{kg} / \mathrm{m}^{2}\right)$; ADL: Activities of daily living.

Table 1c. Distribution of behavioral variables, according to ADL

\begin{tabular}{|c|c|c|c|c|c|c|c|c|c|c|c|c|}
\hline \multirow{3}{*}{ Variables } & & & \multicolumn{8}{|c|}{ ADL Score } & \multirow{3}{*}{$\mathbf{p}$} & \multirow{3}{*}{$\begin{array}{c}\text { Crammer's } \\
\text { V }\end{array}$} \\
\hline & \multicolumn{2}{|c|}{$\begin{array}{c}\text { Total } \\
\mathrm{N}=907\end{array}$} & \multicolumn{2}{|c|}{$\begin{array}{c}\text { Independent } \\
\mathrm{N}=\mathbf{2 8 8}(\mathbf{3 1 . 7 \% )}\end{array}$} & \multicolumn{2}{|c|}{$\begin{array}{c}\text { Mild } \\
\text { dependence } \\
\mathrm{N}=376(41.5 \%)\end{array}$} & \multicolumn{2}{|c|}{$\begin{array}{c}\text { Moderate } \\
\mathrm{N}=114(12.6 \%)\end{array}$} & \multicolumn{2}{|c|}{$\begin{array}{c}\text { Severe } \\
\mathrm{N}=129(14.2 \%)\end{array}$} & & \\
\hline & $\mathbf{N}$ & $\%$ & $\mathbf{N}$ & $\%$ & $\mathbf{N}$ & $\%$ & $\mathbf{N}$ & $\%$ & $\mathbf{N}$ & $\%$ & & \\
\hline Tobacco & & & & & & & & & & & 0.092 & 0.078 \\
\hline Do not smoke & 579 & 64.2 & 182 & 63.2 & 232 & 62.0 & 69 & 60.5 & 96 & 75.6 & & \\
\hline Smoker & 60 & 6.6 & 23 & 8.0 & 22 & 5.9 & 10 & 8.8 & 5 & 3.9 & & \\
\hline Ex-smoker & 264 & 29.2 & 83 & 28.8 & 120 & 32.1 & 35 & 30.7 & 26 & 20.5 & & \\
\hline Alcohol & & & & & & & & & & & 0.307 & 0.063 \\
\hline No & 510 & 56.4 & 172 & 59.9 & 198 & 52.8 & 65 & 57.0 & 75 & 58.1 & & \\
\hline Yes & 395 & 43.6 & 115 & 40.1 & 177 & 47.2 & 49 & 43.0 & 54 & 41.9 & & \\
\hline LTPA & & & & & & & & & & & 0.001 & 0.113 \\
\hline Active & 252 & 27.8 & 103 & 35.8 & 100 & 26.6 & 24 & 21.0 & 25 & 19.4 & & \\
\hline Insuff. active & 159 & 17.5 & 50 & 17.3 & 73 & 19.4 & 20 & 17.6 & 16 & 12.4 & & \\
\hline Inactive & 496 & 54.7 & 135 & 46.9 & 203 & 54.0 & 70 & 61.4 & 88 & 68.2 & & \\
\hline
\end{tabular}

ADL: Activities of daily living; LTPA: Leisure-time physical activity. 
Table 2. Univariate analysis

\begin{tabular}{|c|c|c|c|c|c|c|c|c|c|}
\hline \multirow{3}{*}{ Variables } & \multicolumn{9}{|c|}{ Crude analysis } \\
\hline & \multicolumn{3}{|c|}{ Mild x Independent } & \multicolumn{3}{|c|}{ Moderate $\mathrm{x}$ Independent } & \multicolumn{3}{|c|}{ Severe $\mathrm{x}$ Independent } \\
\hline & OR & $95 \% \mathrm{Cl}$ & $\mathbf{p}$ & OR & $95 \% \mathrm{Cl}$ & $\mathbf{p}$ & OR & $95 \% \mathrm{Cl}$ & $\mathbf{p}$ \\
\hline \multicolumn{10}{|l|}{ Sex } \\
\hline Female $\times$ Male & 0.96 & $0.70-1.32$ & 0.820 & 1.74 & $1.06-2.83$ & 0.027 & 2.24 & $1.37-3.66$ & 0.001 \\
\hline \multicolumn{10}{|l|}{ Age } \\
\hline $70-79$ x 60-69 & 1.44 & $1.03-2.02$ & 0.033 & 2.49 & $1.44-4.29$ & 0.001 & 2.73 & $1.55-4.82$ & 0.001 \\
\hline$\geq 80 \times 60-69$ & 2.31 & $1.45-3.70$ & $<0.001$ & 6.55 & $3.48-12.32$ & 0.001 & 11.32 & $6.07-21.12$ & $<0.001$ \\
\hline \multicolumn{10}{|l|}{ Marital status } \\
\hline Not married x Married & 1.00 & $0.73-1.37$ & 0.987 & 1.50 & $0.97-2.32$ & 0.068 & 2.61 & $1.69-4.02$ & $<0.001$ \\
\hline \multicolumn{10}{|l|}{ Years of study } \\
\hline $4-7 x \geq 8$ & 1.37 & $0.94-1.98$ & 0.098 & 1.79 & $1.08-2.96$ & 0.023 & 2.72 & $1.70-4.37$ & $<0.001$ \\
\hline$\leq 3 x \geq 8$ & 0.81 & $0.41-1.60$ & 0.554 & 2.07 & $0.95-4.51$ & 0.068 & 3.35 & $1.64-6.82$ & 0.001 \\
\hline \multicolumn{10}{|l|}{ BMI } \\
\hline Low weight $x$ Eutrophic & 0.90 & $0.59-1.37$ & 0.615 & 0.76 & $0.39-1.49$ & 0.427 & 0.75 & $0.39-1.43$ & 0.383 \\
\hline Overweight $x$ Eutrophic & 2.38 & $1.40-4.04$ & 0.001 & 1.87 & $0.88-4.01$ & 0.104 & 2.51 & $1.26-5.01$ & 0.009 \\
\hline Obese $x$ Eutrophic & 1.94 & $1.25-3.02$ & 0.003 & 3.23 & $1.85-5.66$ & $<0.001$ & 3.43 & $2.00-5.89$ & $<0.001$ \\
\hline \multicolumn{10}{|l|}{ Income (MW) } \\
\hline $2-3 x \leq 1$ & 1.40 & $0.76-2.61$ & 0.281 & 1.01 & $0.47-2.18$ & 0.969 & 0.70 & $0.35-1.42$ & 0.326 \\
\hline $4-10 x \leq 1$ & 1.17 & $0.67-2.04$ & 0.586 & 0.63 & $0.31-1.27$ & 0.200 & 0.47 & $0.25-0.88$ & 0.019 \\
\hline$>10 x \leq 1$ & 1.60 & $0.84-3.06$ & 0.154 & 0.59 & $0.24-1.43$ & 0.245 & 0.30 & $0.12-0.72$ & 0.007 \\
\hline \multicolumn{10}{|l|}{ Nr diagnoses } \\
\hline $3-6 \times 0-2$ & 1.48 & $0.70-3.15$ & 0.305 & 3.05 & $0.39-23.97$ & 0.290 & 2.56 & $0.32-20.37$ & 0.373 \\
\hline $7-9 \times 0-2$ & 2.72 & $1.27-5.83$ & 0.010 & 10.89 & $1.41-83.77$ & 0.022 & 8.81 & $1.14-68.17$ & 0.037 \\
\hline$\geq 10 \times 0-2$ & 4.04 & $1.86-8.78$ & $<0.001$ & 19.85 & $2.58-152.93$ & 0.004 & 29.78 & $3.89-228.01$ & 0.001 \\
\hline \multicolumn{10}{|l|}{ Nr drugs } \\
\hline $1-4 \times$ None & 1.14 & $0.64-2.02$ & 0.660 & 1.23 & $0.44-3.43$ & 0.694 & 1.99 & $0.57-6.95$ & 0.283 \\
\hline$\geq 5 \times$ None & 1.47 & $0.82-2.62$ & 0.190 & 3.54 & $1.30-9.59$ & 0.013 & 7.29 & $2.15-24.79$ & 0.001 \\
\hline \multicolumn{10}{|l|}{ Dysthymia } \\
\hline Positice $x$ Negative & 1.65 & $1.06-2.57$ & 0.027 & 3.45 & $2.02-5.87$ & $<0.001$ & 6.50 & $3.95-10.69$ & $<0.001$ \\
\hline \multicolumn{10}{|l|}{ LTPA } \\
\hline Insuff Active $x$ Active & 1.50 & $0.96-2.36$ & 0.077 & 1.72 & $0.87-3.40$ & 0.121 & $0.65-2.69$ & 0.447 & 0.447 \\
\hline Inactive $x$ Active & 1.55 & $1.09-2.20$ & 0.015 & 2.22 & $1.31-3.78$ & 0.003 & $1.61-4.48$ & $<0.001$ & $<0.001$ \\
\hline \multicolumn{10}{|l|}{ Tobacco } \\
\hline Smoker x Non-smoker & 0.75 & $0.40-1.39$ & 0.361 & 1.15 & $0.52-2.53$ & 0.735 & $0.15-1.12$ & 0.082 & 0.082 \\
\hline Ex-Smoker x Non-smoker & 1.13 & $0.81-1.59$ & 0.469 & 1.11 & $0.69-1.80$ & 0.666 & $0.36-0.98$ & 0.043 & 0.043 \\
\hline \multicolumn{10}{|l|}{ Alcohol } \\
\hline Yes x No & 1.34 & $0.98-1.82$ & 0.067 & 1.13 & $0.73-1.75$ & 0.593 & $0.71-1.64$ & 0.731 & 0.731 \\
\hline
\end{tabular}

BMI: Body mass index. OR: Odds ratio; LTPA. Leisure-time physical activity. FC: Functional capacity. 
Table 3. Multivariate analysis

\begin{tabular}{|c|c|c|c|c|c|c|c|c|c|}
\hline \multirow{3}{*}{ Variáveis } & \multicolumn{9}{|c|}{ Adjusted analysis } \\
\hline & \multicolumn{3}{|c|}{ Mild x Independent } & \multicolumn{3}{|c|}{ Moderate $\mathrm{x}$ Independent } & \multicolumn{3}{|c|}{ Severe $\mathrm{x}$ Independent } \\
\hline & OR & $95 \% \mathrm{Cl}$ & $\mathbf{p}$ & OR & $95 \% \mathrm{Cl}$ & $\mathbf{p}$ & OR & $95 \% \mathrm{Cl}$ & $\mathbf{p}$ \\
\hline \multicolumn{10}{|l|}{ Sex } \\
\hline Female $\times$ Male & 0.87 & $0.61-1.25$ & 0.460 & 1.37 & $0.78-2.42$ & 0.270 & 1.46 & $0.81-2.62$ & 0.208 \\
\hline \multicolumn{10}{|l|}{ Age } \\
\hline $70-79$ x 60-69 & 1.28 & $0.89-1.85$ & 0.187 & 2.19 & $1.20-4.00$ & 0.011 & 2.92 & $1.52-5.63$ & 0.001 \\
\hline$\geq 80 \times 60-69$ & 2.44 & $1.45-4.10$ & 0.001 & 8.66 & 4.18-17.91 & $<0.001$ & 21.16 & $9.79-45.73$ & $<0.001$ \\
\hline \multicolumn{10}{|l|}{ BMI } \\
\hline Low weight $x$ Eutrophic & 0.93 & $0.59-1.45$ & 0.742 & 0.66 & $0.32-1.38$ & 0.270 & 0.57 & $0.26-1.23$ & 0.151 \\
\hline Overweight $x$ Eutrophic & 2.52 & $1.45-4.37$ & 0.001 & 2.00 & $0.89-4.50$ & 0.095 & 3.12 & $1.41-6.93$ & 0.005 \\
\hline Obese $\mathrm{x}$ Eutrophic & 2.06 & $1.29-3.29$ & 0.002 & 3.41 & $1.82-6.37$ & $<0.001$ & 4.49 & $2.35-8.57$ & $<0.001$ \\
\hline \multicolumn{10}{|l|}{ Nr diagnoses } \\
\hline $3-6 \times 0$ to 2 & 1.31 & $0.58-2.98$ & 0.515 & 1.53 & $0.18-13.06$ & 0.697 & 1.10 & $0.12-10.08$ & 0.933 \\
\hline $7-9 \times 0-2$ & 2.58 & $1.12-5.95$ & 0.026 & 4.92 & $0.59-41.06$ & 0.141 & 2.88 & $0.32-25.94$ & 0.345 \\
\hline$\geq 10 \times 0-2$ & 2.98 & $1.26-7.06$ & 0.013 & 6.00 & $0.71-50.55$ & 0.099 & 5.69 & $0.64-50.78$ & 0.119 \\
\hline \multicolumn{10}{|l|}{ Nr drugs } \\
\hline $1-4 \times$ None & 1.04 & $0.55-1.97$ & 0.898 & 0.98 & $0.32-3.06$ & 0.978 & 1.70 & $0.42-6.77$ & 0.454 \\
\hline$\geq 5 \times$ None & 1.09 & $0.56-2.11$ & 0.800 & 2.03 & $0.66-6.19$ & 0.215 & 3.21 & $0.82-12.54$ & 0.093 \\
\hline \multicolumn{10}{|l|}{ LTPA } \\
\hline Insuff Active $x$ Active & 1.25 & $0.75-2.08$ & 0.393 & 1.41 & $0.64-3.13$ & 0.390 & 0.65 & $0.27-1.51$ & 0.326 \\
\hline Inactive $x$ Active & 1.39 & $0.95-2.03$ & 0.094 & 2.10 & $1.14-3.87$ & 0.018 & 2.02 & $1.10-3.71$ & 0.023 \\
\hline \multicolumn{10}{|l|}{ Dysthymia } \\
\hline Positive $x$ Negative & 1.61 & $0.99-2.62$ & 0.056 & 3.69 & $2.00-6.82$ & $<0.001$ & 6.88 & $3.72-12.76$ & $<0.001$ \\
\hline
\end{tabular}

The Survey on Health, Welfare and Aging (SABE) conducted with 1,479 elders in São Paulo, found that, among the lifestyle conditions, only the PA showed significance. The study indicated that physically inactive elder had 2.88 times the chance of impaired FC, when compared to the actives (Santos et al. 2008), a result very similar to that found by our study.

Similarly, a cross-sectional study with 604 elderlies of Florianópolis, Brazil measured the $\mathrm{FC}$ using the BOMFAQ, the PA using the IPAQ and accelerometes. The results showed that sedentarism is associated with low FC and that high levels of PA contributed to greater independence (Dos Santos et al, 2018).

Using different assessment methods and instruments, other studies also pointed to the strong association between LTPA and FC of elders living in community. A study carried out with 860 elders from the same neighborhood from which the present cohort was selected, showed that more than 4 limitations in ADL were associated with less PA and that the greater the number of difficulties, the greater the possibility of the individual being physically inactive (Ferreira et al, 2010).
A study with 23,694 people aged $\geq 60 y$ from Colombia, found that LTPA was associated with functional limitation and that approximately $80 \%$ of the inactive individuals had difficulty in performing at least one of the ADL (Ballesteros\&Moreno-Montoya, 2018). Both studies, however, have assessed LTPA not with a validated instrument but asking a single question about the practice or not of exercise.

Several systematic reviews have shown the benefits of PA for the health of the elderly, preventing chronic diseases, improving quality of life, increasing muscle mass (Paterson\&Warburton, 2010), reducing the risk of developing functional limitations, favoring social interaction, increasing longevity (Bauman et al, 2015), and benefiting mental health (Windle et al, 2010).

The multivariate analysis of our study reinforce the notion that a network of socio-demographic (age), behavioral (LTPA) and health factors (obesity and dysthimia) determine FC.

Advancing age increased the chance of the elderly presenting more limitation. Elders aged 80 and over in our study, showed more than 20 times the chance of 
exhibiting severe dependence compared with those aged 60 to 69 . Other studies also point to this association that can be understood as a consequence of discrete and continuous losses in vigor, strength, readiness, reaction speed and other functions, characteristics of the aging process (Santos et al, 2008; Artaud et al, 2016; Ballesteros\&Moreno-Montoya, 2018). There is evidence that, in advanced age, older people will experience more limitations and less independence and autonomy in everyday life (Ramos et al, 2001).

Our study found that the obese and overweight elder had a higher chance of having limitations in the ADL than the eutrophic ones, results also found by other studies (Dos Santos et al, 2018; PalaciosCeña et al, 2012). This relationship can be explained because obesity is related to low PA on the part of obese and because excess body fat is associated with the development of CNCD (Jensen\&Hsiao, 2010), contributing to the functional loss.

Our results indicated dysthymia as the variable with the highest strength of association. The elderly with depressive symptoms were 7 times more likely to have severe dependence than the elderly without the symptoms. This association was also pointed out by Ballesteros\&Moreno-Montoya (2018). Bauman et al (2016) pointed that there is evidence that PA can reduce symptoms of depression and improve the mental health among older people. Indeed, depression has been considered one of the leading causes of years lived with disability in the world, compromising the individual's ability to manage their lives independently and autonomously (Murray\&Lopez, 2013).

Despite the strong evidence in favor of the practice of PA for the health of the elder, most of this population is inactive. Among the participants in this study, $72 \%$ were classified as insufficiently active or inactive and they had a higher chance of compromising their FC. High rates of physical inactivity among the elder were also verified in Brazil (78\%) (MS, 2017); and in the world (73\%) (Guthold et al, 2018).

The results of this study reinforce the notion that FC is determined by a wide network of socio-demographic, behavioral and health factors. As in previous studies, this study shows that women, the non-married, those with lower income (Matos et al, 2018), with lower schooling, with a higher number of diagnoses, those who take more than 5 medicines, and those inactives or insufficiently actives have a higher chance of being dependent in daily life (Ballesteros, Moreno-Montoya, 2018; dos Santos et al, 2018; Artaud et al, 2016).

It is important to consider the uniqueness of this sample. It is an elder population with high income and education levels (more than $65 \%$ with 6 or more years of schooling and more than half with income between four and 10 minimum wages). They live in a region with a very high Human Development Index (HDI) (0.970) (PMSP, 2007), even higher than the HDI of Norway, the country leading the human development ranking of the United Nations (0.953) (UNDP, 2018). Despite such high social and economic data, the elder in the neighborhood presented physical inactivity rates similar to the rest of the country (MS,2017).

The present study has some limitations. First, the IPAQ and BOMFAQ evaluate information obtained through self-report that can be influenced by cognitive and emotional alterations or depend on the individual's ability to recall the activities performed in a given period of time. Another limitation refers to the fact that it is a cross-sectional study that associates FC with the LTPA, but does not establish a cause-and-effect relationship.

The identification of factors associated with FC of the elderly provides elements for prevention, promotion and health intervention for this population. The data observed by this research suggest that actions focused on reducing obesity, treating depression and increasing the time spent on LTPA should be encouraged.

\section{CONCLUSION}

Our results suggest that it is worth investing in the promotion of more LTPA time to improve FC of the elderly. As shown, LTPA is associated with FC, which is also influenced by a network of sociodemographic, behavioral and health related factors. It is important to emphasize the relevance of LTPA as a behavioral factor that can possibly be changed. The engagement in LTPA programs is an independent way to reduce and prevent a series of functional losses associated with aging and can contribute to an active and healthy aging.

\section{REFERENCES}

Artaud F, Sabia S, Dugravot A, Kivimaki M, Singh-Manoux A, Elbaz A. Trajectories of unhealthy behaviors in midlife and risk of disability at older ages in the Whitehall II cohort study. J Gerontol A Biol Sci Med Sci. 2016;71(11):1500-6.

Ballesteros SM, Moreno-Montoya J. Context factors associated with functional limitation in the elderly. Cad. Saúde Pública, 2018;34(8):e00163717.

Bauman A, Meron D, Bull FC, Buchner DM, Fiatarone Singh MA. Updating the evidence for physical activity: summative reviews of the epidemiological evidence, prevalence, and interventions to promote Active Aging. Gerontologist. 2016;56(2):268-80.

Craig CL, Marshall AL, Sjöström M, Bauman AE, Booth ML, Ainsworth $\mathrm{BE}$, et al. International physical activity questionnaire: 12 -country reliability and validity. Med Sci Sports Exerc. 2003;35(8):1381-95.

dos Santos CES, Manta SW, Maximiano GP, Confortin SC, Benedetti TRB, d'Orsi E, et al. Accelerometer-measured physical activity and sedentary behavior: a cross-sectional study of Brazilian older adults. J Phys Act Health, 2018;15(11):811-8. 
Ferreira MT, Matsudo SMM, Ribeiro MCSA, Ramos LR. Healthrelated factors correlate with behavior trends in physical activity level in old age: longitudinal results from a population in São Paulo, Brazil. BMC Public Health, 2010;10:690.

Guthold R, Stevens GA, Riley LM, Bull FC. Worldwide trends in insufficient physical activity from 2001 to 2016: a pooled analysis of 358 population-based surveys with 1.9 million participants. The Lancet Global Health, 2018;6(10):1077-86.

Hallal PC, Victora CG. Reliability and validity of the international physical activity questionnaire (IPAQ). Medicine \& Science in Sports \& Exercise, 2004; 36 (3): 556

Jensen GL, Hsiao PY. Obesity in older adults: relationship to functional limitation. Curr Opin Clin Nutr Metab Care. 2010;13(1):46-51.

Lima-Costa MF, Firmo JOA, Uchôa E. The Bambuí Cohort Study of Aging: methodology and health profile of participants at baseline. Cad Saúde Pública. 2011;27(3):327-335.

Matos FS, Jesus CS, Carneiro JAO, Coqueiro R da S, Fernandes $\mathrm{MH}$, Brito TA. Reduced functional capacity of communitydwelling elderly: a longitudinal study. Ciênc Saúde Coletiva. 2018;23(10):3393-401.

MS/Ministério da Saúde (BR). Secretaria de Vigilância em Saúde. Vigitel Brasil 2016: Brasília: MS; 2017. Avaliable in: https:// bvsms.saude.gov.br/bvs/publicacoes/vigitel_brasil_2017_ vigilancia_fatores_riscos.pdf

Murray CJ, Lopez AD. Measuring the global burden of disease. N Engl J Med, 2013;369(5):448-57.

Novais FV, Simoes EJ, Schmaltz C, Ramos LR. Randomized Controlled Trial of Primary Health Care Strategies for the Promotion of Leisure-Time Physical Activity Among Older Brazilians. J Phys Act Health, 2019;17:1-9.

Nunes BP, Batista SRR, Andrade FB, Souza Junior PRB, LimaCosta MF, Facchini LA. Multimorbidade em indivíduos com 50 anos ou mais de idade: ELSI-Brasil. Rev Saude Publica, 2018;52 Supl 2:10s

Palacios-Ceña D, Jiménez-García R, Hernández-Barrera V, AlonsoBlanco C, Carrasco-Garrido P, Fernández-de-Las-Peñas C. Has the Prevalence of Disability Increased Over the Past Decade (2000-2007) in Elderly People? A Spanish Population-based Survey. J Am Med Dir Assoc, 2012; 13(2):136-42.

Paterson DH, Warburton DE. Physical activity and functional limitations in older adults: a systematic review related to Canada's Physical Activity Guidelines. Int J Behav Nutr Phys Act. 2010;7:1-22.

Ramos LR, Goihman S. Geographic stratification by socio-economic status: methodology from a household survey with elderly people in S. Paulo, Brazil. Rev Saúde Pública. 1989;23:478-92.

Ramos LR, Perracini M, Rosa TEC, Kalache A. Significance and management of disability among urban elderly residents in Brazil. Journal of Cross Cultural Gerontology, 1993; 8: 313-323.

Ramos LR, Simões EJ, Albert MS. Dependence in activities of daily living and cognitive impairment strongly predicted mortality in older urban residents in Brazil: a 2-year followup. J Am Geriatr Soc. 2001;49(9):1168-75.

Ramos LR. Fatores determinantes do envelhecimento saudável em idosos residentes em centro urbano: Projeto Epidoso, São Paulo. Cad. Saúde Pública, 2003; 19(3): 793-798.
Ramos LR, Andreoni S, Coelho-Filho JM, Lima-Costa MF, Matos DL, Rebouças $M$, et al. Screening for dependence in activities of daily living in the elderly: minimum set of questions. Rev Saúde Pública. 2013;47(3):506-13.

Ramos LR, Tavares NUL, Bertoldi AD, Farias MR, Oliveira MA, Luiza VL, Pizzol TS, Arrais PSD, Mengue SS. Polypharmacy and Polymorbidity in Older Adults in Brazil: a public health challenge. Revista de Saúde Pública (Online), 2016;50:9s

Rennemark $M$, Jogréus $C$, Elmståhl $S$, Welmer AK, Wimo A, Sanmartin-Berglund J. Relationships between frequency of moderate physical activity and longevity: an 11-year followup study. Gerontol Geriatr Med. 2018;4:1-8.

Santos JLF, Lebrão ML. Duarte YAO. Functional performance of the elderly in instrumental activities of daily living: an analysis in the municipality of São Paulo, Brazil. Cad Saúde Pública. 2008;24(4):879-86.

Simões CCS. Relações entre as alterações históricas na dinâmica demográfica brasileira e os impactos decorrentes do processo de envelhecimento da população. Rio de Janeiro: IBGE; 2016.

Tak E, Kuiper RT, Chorus A, Hopman-Rock M. Prevention of onset and progression of basic ADL disability by physical activity in community dwelling older adults: a metaanalysis. Ageing Res Ver. 2013;12(1):329-38.

UNDESA/United Nations, Department of Economic and Social Affairs, Population Division (2017). World Population Ageing 2017 (ST/ESA/SER.A/408).

UNDP/United Nations Development Programme. Human Development Indices and Indicators, 2018. Avaliable from: http://hdr.undp.org/sites/default/files/2018_human_ development_statistical_update.pdf

U.S. Department of Health and Human Services. Physical Activity Guidelines for Americans, 2nd edition. Washington, DC: U.S. Department of Health and Human Services; 2018. Avaliable in: https://health.gov/paguidelines/secondedition/pdf/Physical_Activity_Guidelines_2nd_edition.pdf

Valerio MP, Novais FV, Ramos L.R. Efeito de duas intervenções visando o aumento do nível de atividade física de idosos inativos no tempo de lazer. Rev Bras Ativ Fis e Saúde, 2014; 19(6): 765-772.

WHO/World Health Organization. Envelhecimento ativo: uma política de saúde / World Health Organization; tradução Suzana Gontijo. - Brasília: Organização Pan-Americana da Saúde, 2005. Avaliable in: http://bvsms.saude.gov.br/bvs/ publicacoes/envelhecimento_ativo.pdf

WHO/World Health Organization. World report on Ageing and Health 2015. Avaliable in: https://www.who.int/ageing/ publications/world-report-2015/en/

Windle G, Hughes D, Linck P, Russell I, Woods B. Is exercise effective in promoting mental well-being in older age? A systematic review. Aging Ment Health. 2010;14(6):652-69.

Zhang W, Feldman MW, Du P. Process of Decline in Activities of Daily Living of Older Chinese People Prior to Death: Evidence From Three Cohorts. Research on Aging, 2019. 